\title{
TNFSF10 wt Allele
}

National Cancer Institute

\section{Source}

National Cancer Institute. TNFSF10 wt Allele. NCI Thesaurus. Code C50962.

Human TNFSF10 wild-type allele is located within $3 q 26$ and is approximately $18 \mathrm{~kb}$ in length. This allele, which encodes tumor necrosis factor lig and superfamily member 10 protein, is involved in the induction and modulation of apoptosis. 